\title{
THE FIRST ALL AFRICA LAW CONFERENCE ON THE INDIVIDUAL UNDER AFRICAN LAW, SWAZILAND, 11-16 OCTOBER, 1981
}

This ambitious conference attracted a wide attendance, not only from the host country and its neighbours in southern Africa, but from other parts of Africa and from farther afield. Its focus was firmly on the human rights situation in Africa as it affects the individual man and woman, in the context of the various kinds of laws, customary, religious, imported and enacted, which now control them. The preliminary papers of the conference stressed three main themes:

(i) a consideration of legal problems arising in legal systems wherein individuals are subjected to competing and often overlapping judicial authorities;

(ii) an identification of human rights problems in the context of selected legal problem areas;

(iii) an analysis of measures that could be useful in solving the problems that present both practical and legal challenges.

The wide scope of the conference is best demonstrated by the main topics of the papers that were presented. A session on the individual, marriage and family law concentrated on the position of women within existing legal systems. The discussions of this topic were notable for the partial polarisation between the sexes that was revealed, a polarisation which had abated by the time the conference came to draw up its final resolutions. Undoubtedly, the inferior status of women in many current African laws is one of the most pressing problems for the legislator; at the same time, the cultural and other obstacles to such a reform were very clearly brought out.

A session on the individual and property ownership brought a further clash of views. In a period when the number of planned and state-controlled economies in Africa is increasing, there must obviously be a sharp discussion both about the success of such economies, and the fundamental principles which should inform the design of a property system. Whose interests are to be paramount, in other words: the individual holder of property, or the community within which he holds that property?

Just as many problems were revealed in a session on the individual and the courts. At the same time successful adaptations of previous judicial systems were brought to notice. Integration of laws, the dual legal system as it affects blacks in the Republic of South Africa, and the goals and problems of law reform in Africa were topics for other sessions.

Despite the liveliness, and even at times the sharpness of the conflict between opposing views, which were manifest in the discussion periods, the most striking features of the conference were first the serious spirit in which participants faced up to the weaknesses of existing legal systems, and secondly, the unanimity with which a set of general resolutions was adopted at the close of the conference. As these resolutions are sure to be of general interest, their text is given below.

\section{Final Resolutions AlL-Africa LaW Conference 11-16 OCTOBER, 1981}

1. The conference recognises the important role which indigenous law has to play in African countries and urges all governments to take the necessary steps to make this concept effective, while having regard to the aim that the indigenous law should be 
encouraged to be dynamic and in consonance with changing economic, social and political conditions.

2. All governments should ensure that their laws in every respect meet the needs and aspirations of the mass of their population for justice, liberty and an adequate material standard of life. Law in Africa can only meet that requirement if it gives an important place, and in some areas of law an all-important place, to the fundamental principles of indigenous law.

3. The meaningful protection of human rights presupposes the following three conditions:

(a) realisation of the right of self-determination;

(b) adherence to the principle of equality; and

(c) participation by those subject to rules that affect their lives in the process by which the state adopts and implements those rules.

4. That this conference, believing that the system of apartheid practised in the Republic of South Africa constitutes a violation of fundamental human rights, unreservedly condemns that system urging all who believe in human rights everywhere to take all steps necessary to bring about the total abolition and eradication of that system.

5. This conference is of the opinion that the status and jurisdictional powers of indigenous courts should be clearly defined by statute and the judicial officers functioning in such courts should be professionally (but not necessarily legally) trained in the conduct of trials, both of civil and criminal matters.

6 . This conference believes that all courts, whether charged with the application of indigenous or received law, in their processes should safeguard fundamental human rights.

7. The conference recognises the vital role and importance which Law Reform Commissions should be allowed to play in the development and understanding of indigenous law, and in addition urges that financial provision be provided by governments for the intensive study of, and research into, indigenous law and to that end provide scholarships, bursaries and other financial aid to persons suitably equipped to make such research possible. The conference considers it imperative that indigenous laws should be properly investigated and recorded in writing in an accessible form for the benefit of courts and those subject to them.

8. The conference declares that any rule, institution or custom which degrades woman or fails to accord her the fundamental rights belonging to every individual is repugnant to justice. In particular the conference calls attention to the injustice of indigenous and received laws which deny woman equality of recognition and treatment in the field of marriage and property rights.

9. The conference expresses the hope that future conferences on law in Africa will be held in other African countries. The formation of an All Africa Law Reform Association should be seriously considered at the next such conference and that to this end this conference should set up an interim All Africa Law Reform Committee consisting of the organisers of the First All Africa Law Conference on the Individual Under African Law. 